\title{
THE 'HOBRECHT PLAN' AND THE EMERGENCE OF THE URBAN
}

\section{Katharina Borsi}

James Hobrecht's Berlin extension plan of 1862 and its architectural component, the Berlin block, continue to define Berlin's current urban structure. The urban structure which these graphic documents helped to deliver persisted despite being rejected through much of the twentieth century. Despite its significance, research on the Hobrecht plan is scarce, and many interpret the plan through its historical context. By contrast, this paper argues that the Berlin block cannot be reduced to representations through its urban plan and architectural component. Instead, they provide a specific urban rationality that poses the question: What is a city? Françoise Choay identified a new urban figure in Ildefonso Cerdá's urban theories, a figure that comes to underlie subsequent theorisations of the urban. The paper argues that the Hobrecht plan and its component block can be read as the graphic and spatial counterpart to Choay's textual figure of the urban.

HOBRECHT

BERLIN BLOCK

CHOAY

URBANISM 


\section{INTRODUCTION}

The 1862 Berlin extension plan is remarkable in its abstraction (Fig. 1). Its lines trace a simple rectilinear pattern over the existing ground. The elements of the drawing are minimal: a primary structure of large streets, extending beyond the edge of the drawing. Grids of different sizes spanning between arteries and radial boulevards are superimposed into the existing map of Berlin. The lines themselves indicate no more than the designation of private and public land; that is, land open for development, and land designated for streets and squares. And yet, this rather minimal graphic information had a powerful and lasting effect on Berlin's urban structure.

The so-called Hobrecht plan of 1862 continues to underlie much of Berlin's current urban structure. ${ }^{1}$ Despite being vilified for much of the 20th century, its urban structure persists until the present day, and since its re-evaluation through the International Building Exhibition in the 1970s, it has come to provide the urban design guidelines for inner-city development. Together with its architectural component, the Berlin block provides a dense, flexibly occupiable urban fabric, characterised by an active ground level, and an organisation that draws the space of the street and the space inside the block closely together (Fig. 2). In the areas developed soon after the publication of the Hobrecht plan, the depth of the urban block, in conjunction with the generous spaces inside the Berlin block, allows a range of different programmes to occupy the spaces - both inside buildings as well as across the depth of the urban block. Housing, offices and workspace of light industries can coexist; programmes requiring larger floorplates can assemble in the depth of the urban block.

The seeming simplicity of the plan provides much ground for the critique of Hobrecht. Already in 1870, the architect Ernst Bruch criticises its 'monotony, uniformity and boredom', a view that continued to resonate with contemporaries and later critics; particularly in comparison to the boulevards of Paris, which were supposedly Hobrecht's model. Bruch argues that the plan also interfered too much with the rights and liberties of private ownership. He felt that the plan should prescribe only the most minimal intervention by focusing solely on main roads. He recommends that the subdivision of land should be dealt with by respective landowners, who, under the guidance of a representative of the public interest, would be able to negotiate an adequate subdivision of the territory. ${ }^{2}$ 


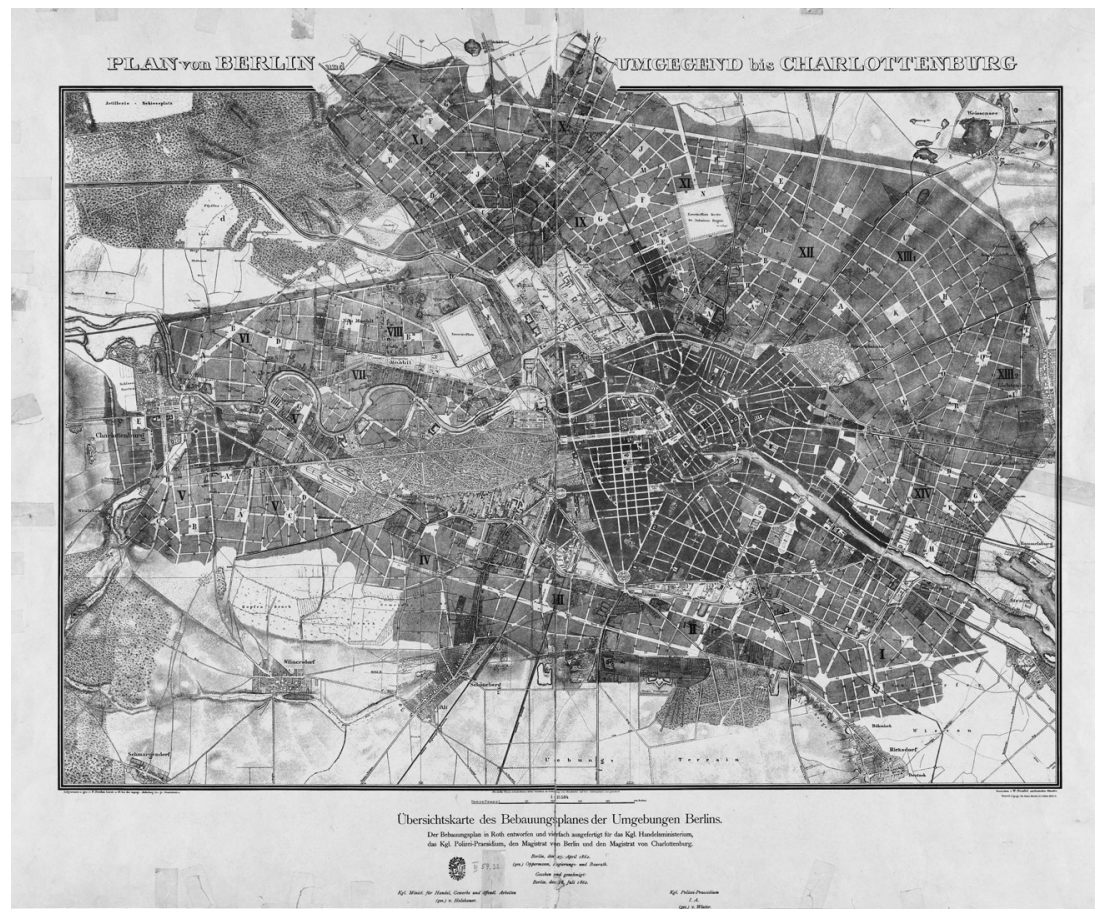

Fig. 1. The Hobrecht Plan. Source: Ferdinand Boehm, Übersichtskarte des Bebauungsplans der Umgebungen Berlins (genehmigt am 18. Juli 1862), Source: Zentral- und Landesbibliothek Berlin, available at: https://digital.zlb.de/viewer/resolver?urn=urn:nbn:de:kobv:109-opus-104224

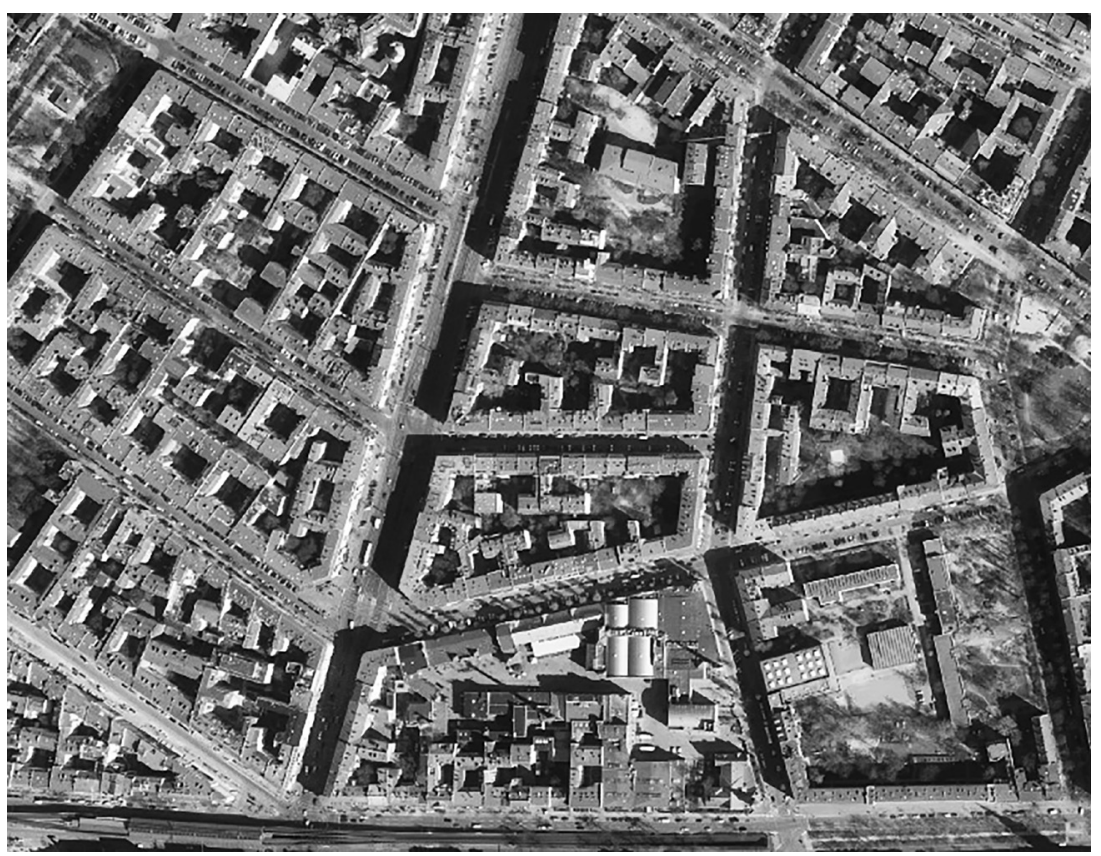

Fig. 2. Berlin Morphology. Source: Geoportal Berlin / [Digitale farbige Orthophotos 2017 (DOP20RGB)], available at http://fbinter.stadt-berlin.de/ 
Rudolf Eberstadt, an influential economist, presented a later position his position on the Hobrecht plan some 40 years later. Writing at a time in which many of the areas had been completely built and densified, Eberstadt declares Hobrecht as being responsible for the excesses of speculation. He argues that the wide streets and deep urban blocks give rise to speculation, propelling land prices and the dense build-up of the urban block through 'rental barracks', the latter embodying all the perceived ills of the nineteenth century; the squalor, overcrowding and lack of adequate living conditions. ${ }^{3}$

This wholesale rejection of the Hobrecht plan and its architectural component, the Berlin block, continued to underlie its reception until its re-evaluation in the 1960s. Since then, the dominant perspective in architectural and urban histories provide more nuanced perspectives on the Hobrecht plan as a planning instrument, and promote the urban qualities of the nineteenth century morphology. Nonetheless, its lack of regulation as to what was being built on the privately-owned land and the minimal prescription in the building regulations persist as a 'crucial flaw', in the words of historian Brian Ladd; and is seen as representative of a liberal and capitalist political order. ${ }^{4}$

What unifies these interpretations is a reading of the Hobrecht plan as an instrument for the negotiation of interests; the lines in plan as representative of the dispute between the public interest of the city versus the private interests of the powerful property owners. However, these interpretations do not explain the particular formal articulation and spatial organisation of the urban morphology brought about the Hobrecht plan, or why it has survived until the present day.

This paper argues that while the lines of the urban plan can be read as representative of the negotiation of interests, they also propose their own immanent rationality. It also proposes a causal link between the Hobrecht plan and the Berlin block, but not as instruments of speculation, rather as providing a joint rationality that poses the question: What is a city? Choay identified a new urban figure in Cerdá's urban theories, a figure that comes to underlie subsequent theorisations of the urban. In the following pages, the Hobrecht plan and its component block is read as the graphic and spatial counterpart to Choay's textual figure of the urban. 


\section{A NEW URBAN FIGURE AND A NEW FIELD}

"The term urbanización, urbanism, town planning, Städtebau, which are used today to describe indiscriminately all of city planning from ancient to modern, were, in fact, formulated for the first time, during the second half of the nineteenth century. Originally, they were intended to mark, with the full impact of a neologism, the advent of an entirely novel relationship between Western man and the organisation of his cities - resulting from the Industrial Revolution. When Ildefonso Cerdà coined the word urbanización in 1867, he meant it to define a new field of activity, as yet 'intact, virgin', for which the Spanish language had no appropriate term."

In The Rule and the Model, Choay argues that the textual figure in Cerdá's urban theories comes to underlie subsequent theorisations of the urban, ranging from der Städtebau, La Cite Industrielle, La Ville Radieuse to Notes on the Synthesis of Form and others. ${ }^{6}$ Choay argues that for Cerdá urbanisation is a phenomenon with its own specificity but without privileged status, accessible to study and governed by laws, like all other phenomena. Cerda postulates that there is a rationality to be discovered beneath the diversity of urban forms, a rationality from which he excludes the elements of chance.

For Cerdá, urbanización is both a process and a product, functioning as both a witness and a sign of 'nuevo mundo', a new civilisation that emerges as the result of the industrial revolution. Choay ties Cerdá's concept of the city to his experience of modernity as a result of industrialisation; the exponential growth of cities and a new mode of inhabiting them, characterised by human circulation, new modes of transport and mass migrations. This experience of modernity is reflected in his definition of the object of the science of urbanism. Cerdá begins by rejecting the notion of a city in its currently accepted form. Instead, he gives it the first functional definition: "Urbanisation resides in nothing other than the relation between rest and movement, or rather between the spaces that accommodate human repose and those that facilitate movement, that is, buildings and the network of streets."

This is precisely what Hobrecht's drawings inscribe. The Berlin extension plan of 1862 that one can see traced in the 'Plan of Berlin and its surroundings' conceived the city as a unified system of interrelated spaces. Hobrecht, who was an engineer was appointed to lead a commission 'for the preparation of a construction plan for the environs of Berlin' in 1859, only one year after his 
professional qualification; the commission had already been examining Berlin's urban development since the mid-1850s. The Hobrecht plan did not propose interventions in the existing fabric. Instead, it projected a grid extending from the existing city, a scaffold that due Berlin's late but exponential process of industrialisation and growth came to be filled with its system of blocks by the turn of the century. Its principle structure consisted of a network of intersecting radial roads and circular arteries, subdividing the new urban structure in relatively equal sections. These areas surrounded by primary roads were further subdivided by secondary roads and regularly interspersed with squares.

The plan was a "compendium of local police regulations determining which lots were to be developed with buildings on the outskirts of the city, and which lots were to be classified as public streets and squares and thus left undeveloped." ${ }^{8}$ Accordingly, the drawing reads as a negative instruction designating the areas to be kept free of buildings - that is, the streets and squares were to achieve an overall connectivity and distribution across the surface of the proposed city. The plan depicts the space of the city as 'full': the new building fabric appears as a solid, a ground of stone out of which the spaces of movement - for air and people, and later drainage - are carved.

Hobrecht declared the regularity and convenience of 'mediating connections' as the primary logic of his plan. Responding to the criticisms of the plan's lack of aesthetic considerations, Hobrecht posited a different logic of the plan: "For the design of streets the question of the size of quarters...the convenience of their mediating communications, (and) the regular distribution of squares are much more important and influential." The resulting urban blocks were designed to allow as much as possible for a later subdivision and different modes of occupation including the expected land needs of industry. The Hobrecht plan was responsive to existing conditions, variable and adaptable. ${ }^{10}$ It sought to address the envisaged urban transformations, and the plan was accordingly designed to allow for growth and movement, testified by later revisions of subsections of the plan.

The logic of the urban plan is mirrored in the logic of its component blocks. Gustav Assmann's Plans for Urban Dwellings, also from 1862, was published as a guide to improve and consolidate the existing knowledge about the construction and spatial organisation of the block. ${ }^{11}$ Assmann provides a relatively complete catalogue rationalising existing variations of the block's organisation in plan depending on the size and the shape of the plot (Fig. 3-5). 

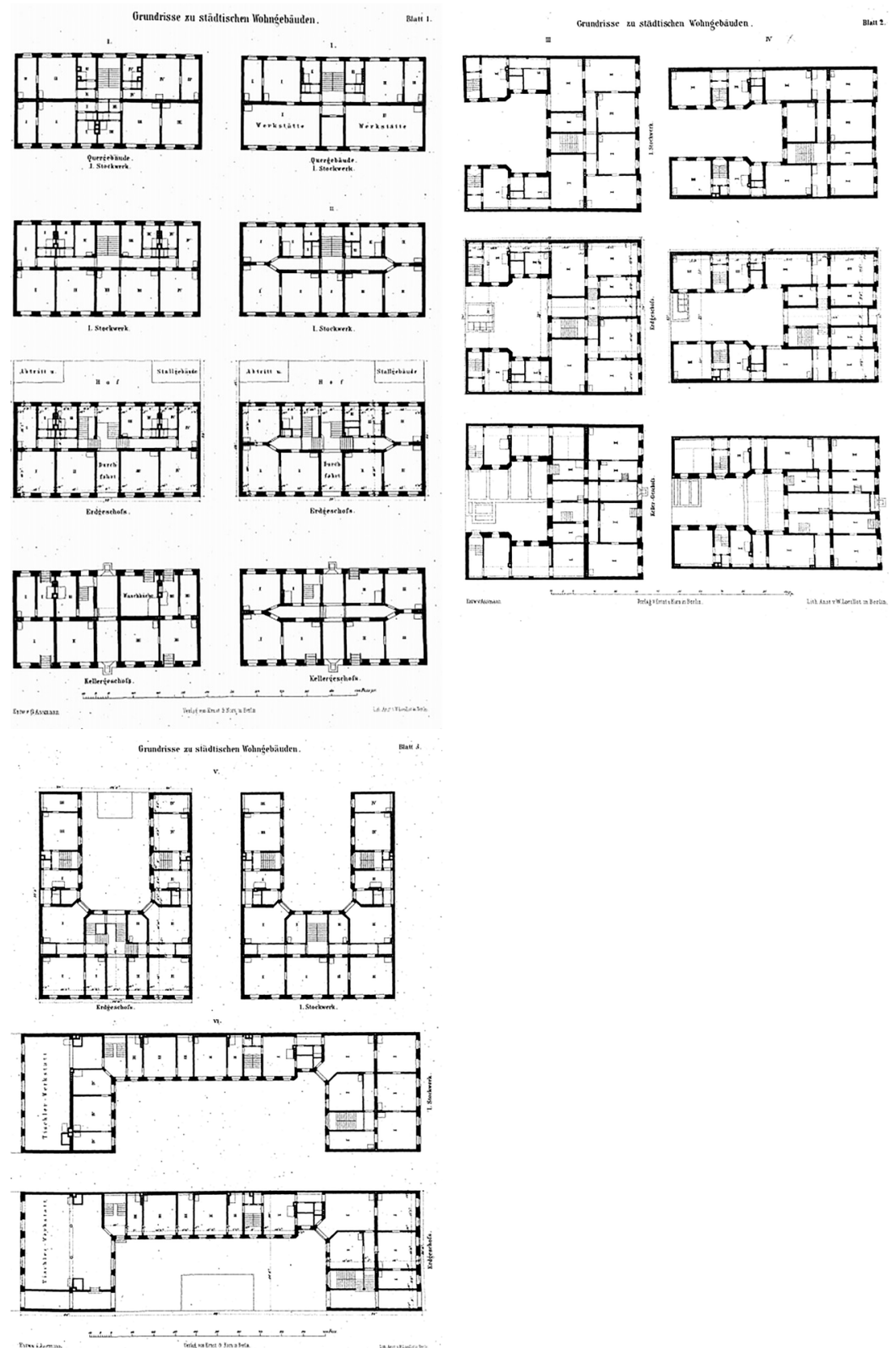

Fig. 3-5. Gustav Assmann, Grundrisse für städtische Wohngebäude 1862. Source: Gustav Assmann, Grundrisse für städtische Wohngebäude, Berlin : Ernst \& Korn, 1862. Digitale Sammlungen der Technischen Hochschule Nürnberg, (available at: http://digital.bib-bvb.de/webclient/DeliveryManager?custom att $2=$ simple viewer\&pid $=8578656$, retrieved 8/3/2018) 
While Assmann saw his book as addressing the need of the poor and those of the middle class, his plans cover all possible forms of accommodation, from a single room dwelling to large apartments up to 14 rooms - to workshops and spaces for industrial use, the latter designated at times as distinct rooms, at times suggested as an interchangeable function. While the captions to his floorplates refer to small, medium and large apartments, in his text he declares flexibility and adaptability in the block's internal organisation as the primary principle of his plans. He describes that the block is subject to "continuously changing occupation by smaller and larger families and their varying demands." ${ }^{\prime 2}$ Assman argues that this "particular mode of occupation restricts any particular and individual disposition'. For this reason, he proposed generous and undifferentiated rooms, without any 'particular forms or unusual size' and 'without any particular architectural features'; construction methods that allow combining small apartments and larger ones into one or subdividing larger apartments if needed. He also introduced door openings in all walls to facilitate the addition or subtraction of rooms to units, and presumably to facilitate the common practice of subletting individual rooms. Assmann summarises that these constraints result in "a certain schemata, which changes according to location, size and form of the urban plot, but essentially allows only minor deviation." 13

Ernst Bruch provides the most succinct summary of the urban principle underlying the joint spatiality between the urban plan and the Berlin block: "The uniform subdivision of streets renders each street into a connection between all possible uses, and each house into a microcosm of the whole of human society."14 The generic urban spaces of the Hobrecht plan, in conjunction with the series of undifferentiated rooms Assmann proposes as its constituent type, provide a flexible infrastructure to accommodate the entire city, an urban system based on inter-connectivity and circulation. Understood in this way, it corresponds to Cerda's definition of urbanisation as "the relation between rest and movement, or rather between the spaces that accommodate human repose and those that facilitate movement, that is, buildings and the network of streets." 15

\section{UNFOLDING VOIDS \& CONCLUSION}

Figure 6 shows a series of plans that share Assmann's logic of the block as an urban system. The plans are building application drawings from blocks located in Moabit and Luisenstadt, two of the earliest areas whose development was accelerated through the publication of the extension plan. The plans share a 
rational organisation, with the façade as defining the space of the street; a generic system of front, side and/or back wings allowing a systematic modularity in filling the urban block; 'quintessential openings' linking the space of the street into the depth of the block to provide access to back buildings; stables and the collective toilets, and an internal organisation that wraps relatively generous and undifferentiated sequence of rooms around the void space of the street and the courtyards. Internally, the plans are organised as a generic assembly of relatively generous, flexibly useable rooms, distributed across a corridor or arrayed as through rooms offering flexibility in the addition and subtraction of spaces, if not through shared corridors, then through the various openings between rooms. It is only towards the end of the nineteenth century that the architectural and urban spaces come to be increasingly formally and functionally differentiated, and the self-contained dwelling of the modern domestic family comes to be generalised. ${ }^{16}$

The plans exemplify the majority of the blocks built in the 1860s; modest individual projects, often developed and owned by tradesmen or members of the lower bourgeoisie. ${ }^{17}$ Their internal organisation has parallels to Assmann's description of the block's interior as a variable number of linked spaces. The space of the room, the corridor, the courtyard and the street do not have the clear lines of demarcation we are used to today. Instead, it appears that these spaces function as a series of interlinking voids with flexibly definable boundaries. Choay described Cerdá's urban system in a similar way: "This way he is led to define the urban body in terms of the combination of two irreducible elements, the building and the means of circulation, whose opposition and combination can account for all levels of the urban framework, from the system of cities interconnected by a universal notion of functionality, down to the house, by way of the city block." 18
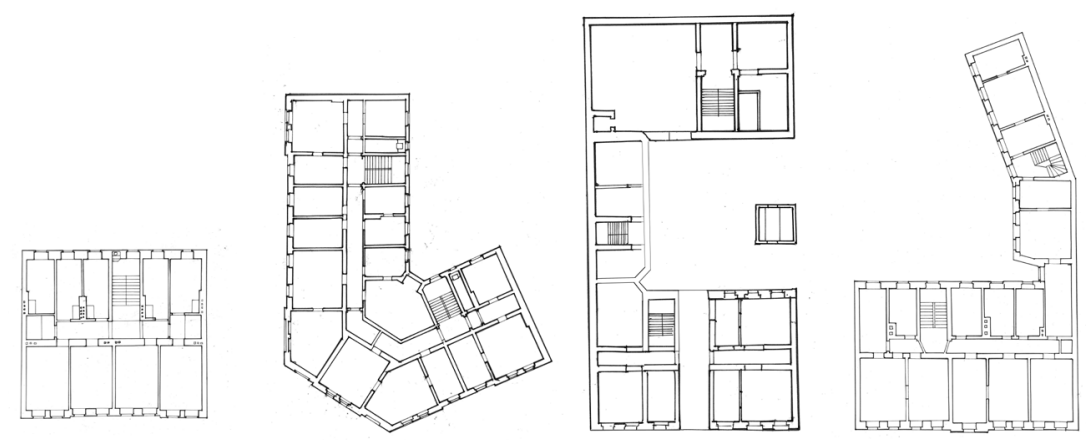

Fig. 6. Plan Sequence: Sorauerstrasse 11, 1862; Birkenstrasse 17, 1874; Oranienstrasse 37, 1862; Birkenstrasse 49, 1872 (drawn by author). 
Both the Hobrecht plan and Cerdá's Teoriá propose generic urban spaces of a similar pattern, a pattern that can accommodate the entire city, in the form of an interlinked spatiality that spans across scales. In the description above, the plan of the block and the urban plan provide the grounds for understanding the city as an infrastructural system that collects and distributes as yet undifferentiated population and a multiplicity of uses throughout its territory.

This is relevant on a number of levels. First, here the lines of the plan are not read as representative of the interests of urban actors, but instead as indicative of a spatial performance in pursuit of the maximum flexibility and adaptability. Secondly, opposed to the critique of the urban plan and the block as an inadequate system of housing and urbanism, the above indicates that these concepts had not been established at the time. This mode of criticism of the architecture and urbanism embodied by the drawings of the block and the urban plan is an anachronism of twentieth century concepts of the self-contained domestic dwelling and the spatial segregation of functions.

As urban historian Gerhard Fehl notes, the flexibility of the urban structure of Berlin allowed it to act as an oscillating 'large sponge' able to absorb an undifferentiated social body in extreme flux, a description that is similar to Cerdá's own description of his blocks as a system of "fluctuating boundaries and an endlessly mobile population." 19

Fehl describes waves of migration, extreme cycles of social mobility, a fluctuating pattern of production and employment cycles as part of the urban reality in a period of radical social and economic transformation. While this provides the rational explanation for the lack of differentiation and flexibility of Berlin's spaces at the time, it also suggests the more general question that the lines in the Hobrecht plan pose.

Similarly to Choay's reading of Cerdá, for the first time, the relationship between the urban subjects and the city is conceptualised together. In other words, the lines in the plan ask: What is the 'nuevo mondo' and what is a city? 
Descriptions and analyses of the Hobrecht plan can be found in Ernst Heinrich, "Der Hobrechtplan", Jahrbuch für brandenburgische Landesgeschichte, (1962); Johann Geist and Klaus Küvers Das Berliner Mietshaus Volumes I, II \& III (Munich: Prestel, 1980, 1984, 1989); and Christopher Bernet, “The 'Hobrecht Plan' (1862) and Berlin's urban structure,” Urban History 31(3), (June 2005): 400-419, https://doi.org/10.1017/S0963926805002622

Ernst Bruch, "Berlins bauliche Zukunft und der Bebauungsplan,” Deutsche Bauzeitung 4 (1870): 104.

Rudolf Eberstadt, Die Spekulation im neuzeitlichen Städtebau (Jena: Fischer, 1910).

Brian Ladd, Urban Planning and Civic Order in Germany, 1860-1914 (Cambridge, Mass.: Harvard University Press, 1990), 82.

Francoise Choay, The Modern City: Planning in the 19th Century (New York, George Braziller, 1969), 7.

Francoise Choay, The Rule and the Model: On the Theory of Architecture and Urbanism (Cambridge,MA: The MIT Press, 1997).

Ibid., 23.

Theodor Striethorst, (ed.): Archiv für Rechtsfälle, die zur Entscheidung des Königlichen Ober-Tribunals gelangt sind, (Berlin: Verlag von J. Guttentag, 1870), 217-218. As quoted in Bernet "The 'Hobrecht Plan," 402.

See quotes by J. Hobrecht in: Geist, "Das Berliner Mietshaus", 158.

See Heinrich, "Bebauungsplan".

Gustav Assmann, Grundrisse für städtische Wohngebäude. Mit Rücksicht auf die in Berlin geltende Bauordnung (Berlin: 1862)

Ibid. 5.

Ibid.

Ernst Bruch, quoted in Dieter Hoffmann Axthelm, Die dritte Stadt. Bausteine eines neuen Gründungsvertrags. (Frankfurt: Suhrkamp, 1993.), 193.

Cerda in Choay, "Rule and Model", 25.

See Katharina Borsi, "Strategies of the Berlin Block," in Intimate Metropolis, edited by V. Di Palma, D. Periton and M. Lathouri (Abingdon, Oxon: Routledge, 2009), 132-152.

See Dieter Hoffmann-Axthelm, Das Berliner Stadthaus, Geschichte und Typologie 1200 - 2010 (Berlin, Dom Publishers, 2011).

Choay, Rule and Model, 241.

Gerhard Fehl , "Berlin wird Weltstadt. Wohnungsnot und Villenkolonien," in Städtebaureform 1865 1900: von Licht, Luft und Ordnung in der Stadt der Gründerzeit, Vol.I, eds. Juan Rodríguez-Lores and Gerhard Fehl (Hamburg: Christians, 1984): 110. 
Assmann, Gustav. Grundrisse für städtische Wohngebäude. Mit Rücksicht auf die in Berlin geltende Bauordnung. Berlin: 1862.

Bernet, Christopher, “The 'Hobrecht Plan' (1862) and Berlin's urban structure.” Urban History 31(3), (June 2005): 400-419. https://doi.org/10.1017/S0963926805002622.

Borsi, Katharina. "Strategies of the Berlin Block." In Intimate Metropolis, edited by V. Di Palma, D. Periton and M. Lathouri, 132-152. Abingdon, Oxon: Routledge, 2009.

Bruch, Ernst. "Berlins bauliche Zukunft und der Bebauungsplan.” Deutsche Bauzeitung 4 (1870): 69-71; 77-80; 93-95; 101-104; 121-122; 129-130; 151-154; 159-163; 167-168; 183-186; 191-193; 199-201.

Choay, Francoise. The Modern City: Planning in the 19th Century. New York: George Braziller, 1969.

Choay, Francoise. The Rule and the Model: On the Theory of Architecture and Urbanism. Cambridge, MA: The MIT Press, 1997.

Eberstadt, Rudolf. Die Spekulation im neuzeitlichen Städtebau. Jena: Fischer, 1910.

Fehl, Gerhard. "Berlin wird Weltstadt. Wohnungsnot und Villenkolonien." In Städtebaureform 18651900: von Licht, Luft und Ordnung in der Stadt der Gründerzeit, Vol.I, edited by Juan RodríguezLores and Gerhard Fehl, 101-152. Hamburg: Christians, 1984.

Geist, Johann and Klaus Küvers. Das Berliner Mietshaus Volumes I, II \& III. Munich: Prestel, 1980, 1984, 1989

Heinrich, Ernst. "Der Hobrechtplan.” Jahrbuch für brandenburgische Landesgeschichte (1962): 41-58.

Hoffmann Axthelm, Dieter. Die dritte Stadt. Bausteine eines neuen Gründungsvertrags. Frankfurt, Suhrkamp, 1993.

Hoffmann Axthelm, Dieter. Das Berliner Stadthaus, Geschichte und Typologie 1200-2010. Berlin: Dom Publishers, 2011.

Ladd, Brian, Urban Planning and Civic Order in Germany, 1860-1914. Cambridge, Mass.: Harvard University Press, 1990. 